\title{
Subject Characteristics Data Collection Date Time
}

National Cancer Institute

\section{Source}

National Cancer Institute. Subject Characteristics Data Collection Date Time. NCI

Thesaurus. Code C83397.

The date and time subject characteristic data was collected. 